\title{
KEMAMPUAN SPIRITUALITAS DAN TINGKAT STRES PASIEN DIABETES MELLITUS DI RUMAH PERAWATAN: STUDI PENDAHULUAN
}

\author{
Tiara Suciani, Tuti Nuraini* \\ Fakultas Ilmu Keperawatan Universitas Indonesia, Depok 16424, Indonesia \\ *Email: tutinfik@gmail.com
}

\begin{abstract}
Abstrak
Spiritualitas merupakan salah satu hal yang terpenting dalam hidup seseorang, termasuk bagi pasien diabetik. Spiritualitas digambarkan sebagai pengalaman yang paling tinggi, hubungan yang lebih mendalam yang dirasakan terhadap Tuhan, sesama, termasuk terhadap alam. Studi pendahuluan ini bertujuan mengidentifikasi hubungan antara kemampuan spiritualitas dan tingkat stres pasien diabetes yang melakukan perawatan luka di rumah perawatan. Penelitian potong lintang ini melibatkan sampel sebanyak 64 responden pasien diabetes di rumah perawatan di wilayah Jabodetabek, dengan teknik consecutive sampling. Instrumen yang digunakan adalah modifikasi dari Multidimensional Measure of Religiousness/Spirituality, Spiritual Involvement and Belief Scale Revised Version, Spiritual Health, and Life-Orientation Measure dan kuesioner Depression Anxiety Stress Scales (DASS). Hasil penelitian menujukkan bahwa tidak terdapat hubungan yang signifikan $(\mathrm{p}=0,219 ; \mathrm{p}<0,05)$ antara kemampuan spiritualitas dan tingkat stres, namun secara klinis penelitian ini cukup bermakna karena responden dengan tingkat stres normal memiliki rerata kemampuan spiritualitas yang lebih tinggi dibanding kategori lainnya. Studi lanjutan perlu dilakukan untuk menguji hubungan factor lainnya terhadap kemampuan spiritual dan tingkat stress. Kemampuan spiritualitas pasien diabetik ini perlu lebih diperhatikan oleh seorang perawat ketika memberikan asuhan keperawatan pada pasien diabetikum sehingga dapat menunjang aspek lainnya yang berkontribusi dalam kemampuan perawatan diri pasien.
\end{abstract}

Kata kunci: kemampuan spiritualitas, pasien diabetes, tingkat stres

\begin{abstract}
The Ability of Spirituality and Stress Level of Patients with Diabetes Mellitus in Home Care Setting: A Preliminary Study. Spirituality is one of the important things in patients' life, including patients with diabetes. Spirituality is defined as the highest experience of a deeper connection feeling to God, others, and nature. This preliminary study aimed to identify the relationship between the ability of spirituality and stress level of diabetic patients in-home care setting. In this study, the design method was cross-sectional with 64 respondents of the diabetic patient at several home care settings in Jabodetabek area, which used consecutive sampling technique. The instrument used a modification of Multidimensional Measure of Religiousness/ Spirituality, Spiritual Involvement and Belief Scale-Revised Version, Spiritual Health And Life-Orientation Measure and questionnaires Depression Anxiety Stress Scales. The result showed that there was no significant relationship ( $p=0.219 ; p<0.05)$ between the ability of spirituality and stress levels, but this research was clinically significant because the respondents with normal stress levels have a higher average spiritual capability than other categories. Further study need to undertake to determine the relationship between the other factors toward spirituality ability and the stress level. The ability of spirituality of patient with diabetes needs more attention by a nurse when providing nursing care to the diabetic patient to support other aspects that contribute in the patient self-care capability.
\end{abstract}

Keywords: diabetic patients, spirituality, stress level

\section{Pendahuluan}

Penyakit diabetes mellitus adalah penyakit kronis progresif yang ditandai dengan ketidak- mampuan tubuh untuk melakukan metabolisme karbohidrat, lemak, dan protein, mengarah ke hiperglikemia atau kadar glukosa darah yang tinggi (Black \& Hawks, 2008/2014). 
Menurut International Diabetes Federation (IDF) orang yang hidup dengan diabetes pada tahun 2013 diperkirakan sekitar 382 juta orang dan akan terus meningkat jumlahnya menjadi 592 juta orang pada tahun 2035 di seluruh dunia. Data juga menunjukkan lebih dari $80 \%$ kematian akibat diabetes terjadi di negara dengan pendapatan rendah dan sedang (IDF, 2015).

Menurut data IDF (2015) di kawasan Pasifik Barat sebanyak 1,9 juta kematian disebabkan oleh penyakit diabetes mellitus, dan $45 \%$ diantaranya berusia di bawah 60 tahun. Hasil Riskesdas tahun 2013 jumlah penderita diabetes mellitus di Indonesia yang berusia di atas 15 tahun sekitar 12 juta orang (Kemenkes RI, 2014). Selain itu, proporsi penderita DM di perkotaan meningkat dari $6,8 \%$ di tahun 2007 menjadi $7 \%$ di tahun 2013. Untuk proporsi TGT (Toleransi Glukosa Terganggu) meningkat pesat dari $10,20 \%$ di tahun 2007 menjadi $29,9 \%$ di tahun 2013.

Seperti penyakit kronis lain, diabetes mellitus merupakan penyakit dengan waktu yang lama dan umumnya perkembangan penyakitnya lambat (WHO, 2014). Hal ini membuat individu menjadi mudah stres, karena setiap orang pada dasarnya rentan mengalami stres. Lebih dari 50 persen pasien kronis mengalami stres ringan sampai sedang, sesuai dengan beberapa hasil penelitian tentang tingkat stres pada pasien dengan penyakit kronik (Sandra, Dewi, \& Dewi, 2012; Sofiana, Elita, \& Utomo, 2012).

Stres berkepanjangan ini akan meningkatkan kerentanan terhadap penyakit karena hormon stres menghambat sel $\mathrm{T}$ dan aktifitas makrofag serta mengurangi jumlah limfosit yang beredar (Saladin, 2011). Jika hal ini terjadi tentunya akan semakin menurunkan sistem pertahanan tubuh terhadap penyakit sehingga menambah parah penyakit yang diderita. Selain itu stres adalah salah satu faktor yang memengaruhi proses penyembuhan luka. Gouin dan KiecoltGlaser (2011), dalam penelitiannya menunjukkan bahwa stres psikologis yang dialami pasien akan memengaruhi oksitosin, glukokotokoid, katekolamin, dan perilaku hidup sehat sehingga menunda proses penyembuhan luka.

Stres dan penderitaan yang dialami setiap individu yang didiagnosis penyakit diabetes mellitus tentu berbeda, dan memiliki koping tersendiri. Individu menggunakan berbagai strategi koping untuk mengelola perasaan negatif yang mereka timbulkan. Makhija (2002) menjelaskan bahwa sumber koping saat individu merasakan sakit, dan merasakan penderitaan adalah agama dan spiritual. Agama dan spiritual dapat menjadi sumber harapan dalam menghadapi rasa sakit, perasaan depresi, dan perasaan menderita (Zehtab \& Adib-Hajbaghery, 2014).

Gupta dan Anandarajah (2014) dalam penelitiannya mewawancarai 18 responden terkait peran spiritual terhadap diri dengan penyakit diabetesnya memperoleh hasil bahwa semua responden merasa nyaman saat membicarakan peran spiritualitas terutama mengenai kepercayaan dan harapan dalam menghadapi penyakit diabetes. Selain itu, terdapat peningkatan pe-rawatan diri pada pasien diabetes, seperti kontrol gula darah pada pendidikan berbasis agama (Lynch, Hernandez-Tejada, \& Egede, 2012). Hasil penelitian Ningrum (2014) menunjukkan bahwa sebanyak 92\% responden mempunyai tingkat spiritualitas yang tinggi dan sisanya memiliki spiritualitas yang rendah. Hal ini menunjukan umumnya pasien yang memiliki penyakit kronis mempunyai tingkat spiritualitas yang baik.

Penelitian yang menghubungkan antara kemampuan spiritualitas dan tingkat stres perlu dilakukan pada pasien diabetes. Sejauh ini penelitian tentang spiritualitas dan tingkat stres pada pasien diabetes mellitus masih berdiri sendiri-sendiri, dan penelitian pada pasien diabetes mellitus yang mendapat perawatan di rumah perawatan belum dilakukan dalam konteks Indonesia.

Tujuan penelitian ini adalah untuk menguji hubungan kemampuan spiritualitas dengan ting- 
kat stres pada pasien diabetes mellitus di rumah perawatan. Hipotesis dari penelitian ini yaitu terdapat hubungan antara kemampuan spiritualitas dan tingkat stres pada pasien diabetes.

\section{Metode}

Penelitian potong lintang ini dilakukan dengan melibatkan sebanyak 64 pasien diabetes mellitus sebagai responden. Pengambilan sampel menggunakan metode consecutive sampling. Penelitian dilakukan di Rumah Perawatan di Wilayah Jakarta, Tangerang, Bekasi, dan Bogor. Penelitian ini juga telah melalui prosedur administrasif ada etik. Tidak ada conflict of interest, dan etika penelitian diterapkan dalam setiap tahap penelitian.

Kuesioner yang digunakan pada penelitian ini yaitu Multidimensional Measure of Religiousness/Spirituality, dan Spiritual Involvement and Belief Scale Revised Version untuk mengukur kemampuan spiritualitas. Untuk mengukur tingkat stres menggunakan kuesioner Depression Anxiety Stress Scales. Masing-masing pernyataan diambil dari kuesioner tersebut, kemudian dimodifikasi, dan melalui prosedur penerjemahan ke dalam Bahasa Indonesia. Kuesioner spiritualitas terdiri dari 16 pernyataan dan kuesioner tingkat stres terdiri dari 14 pernyataan, keduanya memakai skala likert.

Hubungan antara kemampuan spiritualitas dengan tingkat stres memakai uji anova satu arah. Proses asupan data dan analisis data dilakukan dengan bantuan program komputer.

\section{Hasil}

Karakteristik responden berdasarkan usia, jenis kelamin, tingkat pendidikan, dan penggunaan insulin. Mayoritas responden berada pada rentang usia dewasa menengah atau usia 35-60 tahun $(93,8 \%)$, berjenis kelamin perempuan $(59,4 \%)$, berpendidikan sedang $(50,0 \%)$, dan tidak menggunakan insulin $(89,1 \%)$. Secara detil karakteristik responden dapat dilihat pada Tabel 1.

Pada Tabel 2 menjelaskan tentang distribusi frekuensi kemampuan spiritualitas dan masingmasing domain yang diukur. Rerata kemampuan spiritualitas pada responden di rumah perawatan sebesar 46,39, sedangkan pada masing-masing domain, reratanya adalah domain transenden 15,38 , domain personal 11,92 , domain komunal 11,09, dan domain lingkungan 8,00 .

Tabel 1. Karakteristik Responden

\begin{tabular}{lcc}
\hline \multicolumn{1}{c}{ Variabel } & Jumlah (n) & Persentase (\%) \\
\hline Usia & 4 & 6,3 \\
a. Dewasa Awal & 60 & 93,8 \\
b. Dewasa Menengah & & \\
Jenis Kelamin & 38 & 59,4 \\
a. Perempuan & 26 & 40,6 \\
b. Laki-laki & & \\
Tingkat Pendidikan & 26 & 40,6 \\
a. Pendidikan rendah & 32 & 50,0 \\
b. Pendidikan sedang & 6 & 9,4 \\
c. Pendidikan tinggi & & \\
Penggunaan Insulin & 7 & 10,9 \\
a. Menggunakan insulin & 57 & 89,1 \\
b. Tidak menggunakan insulin & & \\
\hline
\end{tabular}


Tabel 2. Kemampuan Spiritualitas Responden

\begin{tabular}{lccc}
\hline \multicolumn{1}{c}{ Varibel } & Rerata & SD & $95 \%$ CI \\
\hline Kemampuan spiritualitas & 46,39 & 4,085 & 45,$37 ; 47,41$ \\
& & & \\
Domain spiritualitas & 15,38 & 1,57 & 14,$98 ; 15,77$ \\
a. Transenden & 11,92 & 1,83 & 11,$46 ; 12,38$ \\
b. Personal & 11,09 & 1,38 & 10,$75 ; 11,44$ \\
c. Komunal & 8,00 & 1,45 & 7,$64 ; 8,36$ \\
d. Lingkungan & & & \\
\hline
\end{tabular}

Tabel 3. Tingkat Stres Responden

\begin{tabular}{lcc}
\hline \multicolumn{1}{c}{ Variabel } & Jumlah $(\mathrm{n})$ & Persentase $(\%)$ \\
\hline Tingkat stres & & \\
a. Normal & 53 & 82,8 \\
b. Stres ringan & 8 & 12,5 \\
c. Stres sedang & 3 & 4,7 \\
d. Stres Berat & 0 & 0 \\
e. Stres sangat berat & 0 & 0 \\
\hline
\end{tabular}

Tabel 4. Kemampuan Spiritualitas dan Tingkat Stres

\begin{tabular}{lccccc}
\hline & & n & Rerata & SD & p \\
\hline Tingkat stres & Normal & 53 & 46,79 & 4,17 & \\
& Ringan & 8 & 44,25 & 3,53 & 0,219 \\
& Sedang & 3 & 45 & 2 & \\
\hline
\end{tabular}

Tabel 3 merupakan distribusi frekuensi variabel tingkat stres. Hasil penelitian menunjukkan bahwa sebanyak $82,8 \%$ responden memiliki tingkat stres yang normal yaitu sebanyak 57 responden.

Tabel 4 menunjukkan bahwa hasil analisis hubungan antara kemampuan spiritualitas dengan tingkat stres. Uji statistik yang dilakukan yaitu uji anova. Responden dengan tingkat stres yang normal merupakan yang paling banyak diantara tingkatan yang lainnya dengan rerata kemampuan spiritualitas sebesar 46,79. Hasil uji analisis statistik didapatkan nilai $\mathrm{p}=0,219$ sehingga lebih dari nilai $\alpha(0,05)$, hal ini membuktikan bahwa tidak ada hubungan yang bermakna antara kemampuan spiritualitas dengan tingkat stres pada pasien diabetes mellitus yang mendapatkan perawatan di rumah perawatan wilayah Jabodetabek.

\section{Pembahasan}

Penelitian ini memilih usia dewasa sebagai responden. Kategori usia yang dipakai dibagi menjadi dua bagian yaitu dewasa muda dengan rentang umur 20 sampai 34 tahun, dan dewasa menengah dengan rentang usia 35 sampai 60 tahun.

Hasil penelitian ini melaporkan bahwa kemampuan spiritualitas responden dalam rentang skala yang baik. Skala tertinggi diperoleh pada domain transenden. 
Rogers dan Wattis (2015) menyimpulkan spiritualitas sebagai dimensi pengalaman manusia yang khas, berpotensi kreatif dan universal, yang timbul baik dalam pengalaman subyektif batin individu maupun dalam komunitas, kelompok sosial dan tradisi. Ini mungkin dialami sebagai hubungan dengan apa yang disebut secara intim dalam "batin", imanen dan pribadi di dalam diri sendiri dan orang lain, dan atau sebagai suatu hubungan dengan apa yang disebut sepenuhnya "lain", transenden dan di luar diri. Ini juga dialami sebagai sesuatu yang mendasar atau sangat penting dan karena itu memperhatikan pada makna dan tujuan hidup, kebenaran dan nilai-nilai yang dianut.

Domain spiritualitas digambarkan beragam oleh banyak literature. Johnson, et al. (2011) menjelaskan bahwa domain spiritual mencakup koping spiritual, kesejahteraan spiritual, riwayat spiritual, iman dan kepercayaan, dan partisipasi religius. Fisher (2011) menjelaskan ada empat domain kesejahteraan spiritual yaitu domain personal yakni tempat seseorang intra-relasi dengan diri sendiri; domain komunal, dengan hubungan inter-personal yang mendalam; domain lingkungan, koneksi dengan alam; dan domain transendensi, relasi kepada sesuatu atau seseorang di atas level manusia.

Hasil penelitian ini dapat dipahami mengingat kondisi di Indonesia dengan masyarakat yang religius. "Ketuhanan yang maha Esa" merupakan sila pertama dari Pancasila sebagai dasar negara. Sebuah survei juga menunjukkan bahwa tenaga kesehatan di Indonesia memiliki tingkat religiusitas lebih tinggi dibandingkan koleganya dari Brasil dan India (Lucchetti, et al., 2016). Meskipun religiusitas dan spiritualitas merupakan halyang berbeda tetapi seringkali tumpang tindih. Wattis dan Curran (2006), dalam konteks pelayanan kesehatan, agama itu berkaitan dengan kepercayaan dan ritual yang ditemukan dalam banyak bentuk keimanan dan seringkali dihubungkan dengan struktur kekuasaan. Definisi agama menurut mereka mencakup makna yang digunakan oleh manusia untuk berhubungan dengan Tuhan, seperti sembahyang atau berdoa. Tumpang tindih terjadi karena masyarakat akan memandang keimanan mereka sebagai inti dari spiritualitas mereka. Namun, banyak yang akan menegaskan bahwa seseorang dapat menjadi spiritual tanpa religius, atau religius tanpa spiritual (Cook, Powell, \& Sims, 2010).

Hasil penelitian menunjukkan tingkat stres responden termasuk kedalam kategori normal yaitu sebanyak 53 responden $(82,8 \%)$ dari total keseluruhan 64 responden. Kondisi ini menyimpulkan bahwa pasien diabetes mellitus yang di rumah perawatan tidak mengalami stres yang tinggi, karena masih dikatakan normal terjadi pada individu. Hasil ini berbeda dengan penelitian yang menyebutkan bahwa lebih dari 50 persen pasien kronis mengalami stres ringan sampai sedang (Sandra, et al., 2012; Sofiana, et al., 2012). Kondisi responden pada penelitian ini baik mengingat beberapa studi sebelumnya menyebutkan bahwa stres psikologis dapat meningkatkan konsentrasi gula darah pada pasien diabetes mellitus tipe 2 (Faulenbach, et al., 2012; Lloyd, Smith, \& Weinger, 2005). Wiesli, et al. (2005) bahkan melaporkan bahwa pada pasien diabetes mellitus tipe 1, kondisi stress psikologis memperlambat penurunan gula darah selepas mendapat asupan makanan tetapi pada kondisi puasa tidak ditemukan gejala apapun.

Spiritualitas merupakan salah satu koping individu untuk menangani stres dan pengambilan keputusan pengobatan (Johnson, et al., 2011). Koenig (2012) menyebutkan spiritualitas mempunyai peranan penting dalam menurunkan stres. Penelitian kualitatif dari Gupta, et al. (2014) tentang peranan spiritualitas dalam manajemen kesehatan pada pasien diabetes menunjukan terdapat peranan yang cukup signifikan. Hasil yang sama juga diungkapkan oleh Johnson, et al. (2011) bahwa kesejahteraan spiritual saat ini dan pengalaman relijius masa lalu berhubungan dengan gejala kecemasan dan depresi. Hasil dari berbagai penelitian tersebut tidak sejalan dengan hasil penelitian ini. Walaupun secara uji statistika tidak terdapat hubungan yang bermakna, namun nilai rerata 
kemampuan spiritualitas setiap tingkatan stres dapat dilihat bahwa nilai rerata yang paling tinggi masuk kedalam kategori stres normal, sehingga tampak bahwa responden dengan tingkat stres yang normal memiliki nilai rerata kemampuan spiritualitas yang paling tinggi dibandingkan responden dengan tingkat stres ringan dan sedang.

Perbedaan hasil ini dapat disebabkan karena beberapa hal. Mayoritas responden mengalami tingkat stres yang normal $(82,8 \%)$ sehingga secara statistik kedua variabel tersebut tidak menunjukkan hubungan yang bermakna.

Perbedaan hasil penelitian ini juga kemungkinan karena besar sampel yang kecil dan sebaran karakteristik individu yang tidak merata. Usia responden relatif dalam kategori yang sama sehingga nilai kemampuan spiritualitasnya juga relatif sama. Chaves dan Gil (2015), melaporkan orang lanjut usia menyadari pentingnya kemampuan spiritualitas, dikaitkan dengan pengalaman hidup dan kapasitas mereka untuk beradaptasi terhadap keterbatasan, kehilangan dan kesulitan lainnya.

Hal lain yang kemungkinan menyebabkan tidak ditemukannya perbedaan tingkat stres responden karena mereka berada pada lingkungan yang sama, yaitu rumah perawatan. Dukungan dari keluarga yang membuat pasien memiliki semangat dan berusaha selalu berpikiran positif, serta pemberian dukungan, motivasi dari pemberi pelayanan kesehatan untuk terus meningkatkan ibadah dan selalu berpikiran positif.

Penelitian ini merupakan studi pendahuluan yang hanya melibatkan sejumlah kecil responden dan tidak melakukan uji korelasi terhadap faktor lain yang kemungkinan berhubungan dengan tingkat stres pasien diabetes di rumah perawatan, baik faktor internal maupun eksternal. Kemampuan spiritualitas juga belum mencakup aspek religiutas yang kemungkinan tumpang tindih.
Hasil penelitian ini menegaskan pentingnya layanan keperawatan yang mencakup kebutuhan spiritual pasien. Hubungan spiritualitas dengan harapan, makna dan tujuan dalam hidup, kepercayaan dan nilai merupakan hal yang penting dalam praktik keperawatan. Hal ini membantu memenuhi kebutuhan untuk mempromosikan pendekatan yang berpusat pada pasien. Kunci untuk memberikan perawatan spiritual adalah dengan memahami arti spiritualitas bagi orang yang berarti (Gordon, Kelly, \& Mitchell, 2011).

Roger dan Wattis (2014) mengatakan bahwa pendekatan yang berpusat pada pasien adalah pendekatan yang paling efektif dalam masyarakat multi-kultural, multi-agamatempat beberapa orang yang menganggap bahwa sains telah menyangkal Tuhan dan menemukan makna dan tujuan mereka di luar agama, sementara yang lain terus melakukannya melalui keyakinannya terhadap agama. Hal ini tentu penting dalam konteks masyarakat Indonesia yang menghubungkan setiap aspek kehidupan dengan keyakinan dan agamanya.

\section{Kesimpulan}

Hasil penelitian menujukkan bahwa tidak terdapat hubungan yang signifikan antara kemampuan spiritualitas dan tingkat stres pasien diabetes mellitus di rumah perawatan, namun secara klinis penelitian ini cukup bermakna karena responden dengan tingkat stres normal memiliki nilai rerata kemampuan spiritualitas yang lebih tinggi daripada kategori tingkat stres lainnya. Hal ini dapat dijadikan sebagai bahan evaluasi untuk meningkatkan dan menjaga kemampuan spiritualitas pasien dengan cara mengingatkan kepada Tuhan, alam, ataupun berbuat baik kepada sesama, serta menjaga kualitas pemberian manajemen stres pada pasien DM yang melakukan perawatan luka di rumah perawatan. Untuk meningkatkan dan menjaga kualitas tersebut tentu dibutuhkan staf perawat klinis yang mempunyai kompetensi cukup ting- 
gi. Oleh karena itu, institusi pelayanan praktik keperawatan mandiri dapat memilih atau meningkatkan tingkat pendidikan stafnya agar keterampilan komunikasi, berpikir kritis, kepemimpinan, manajemen kasus, serta promosi kesehatan akan lebih baik (KK, YU, INR).

\section{Ucapan Terima Kasih}

Ucapan terimakasih disampaikan kepada Kepala dan kolega perawat di Rumah Perawatan di Jabodetabek.

\section{Referensi}

Black, J.M., \& Hawks, J.H. (2014). Keperawatan medikal bedah: Manajemen klinis untuk hasil yang diharapkan. (R.A. Nampira, Yudhistira, S.C. Eka, penerjemah). Singapore: Elsevier. Buku asli diterbitkan tahun 2008.

Chaves, L.J., \& Gil, C.A. (2015). Older people's concepts of spirituality, related to aging, and quality of life. Ciência \& Saúde Coletiva, 20 (12), 3641-3652. https://dx.doi.org/10.1590 /1413-812320152012.19062014

Cook, C., Powell, A., \& Sims, A. (Eds). (2010). Spirituality and psychiatry. London: RS Psych Publications.

Faulenbach, M., Uthoff, H., Schwegler, K., Spinas, G.A., Schmid, C., \& Wiesli, P. (2012). Effect of psychological stress on glucose control in patients with Type 2 diabetes. Diabet Med, 29 (1), 128-131. doi: 10.1111/j.1464-5491. 2011.03431.x.

Fisher, J. (2011). The four domains model: Connecting spirituality, health, and wellbeing. Religions, 2 (4), 17-28. MDPI AG. Retrieved from http://dx.doi.org/10.3390/rel 2010017

Gouin, J.P., \& Kiecolt-Glaser, J.K. (2011). The impact of psychological stress on wound healing: Methods and mechanisms. Immunology and Allergy Clinics of North America, 31(1), 81-93. http://doi.org/10.1016/j.iac.20 10.09.010
Gordon, T., Kelly, E., \& Mitchell, D. (2011). Spiritual care for healthcare professionals: Reflecting on clinical practice. London: Radcliffe Publishing.

Gupta, P.S., \& Anandarajah, G. (2014). The role of spirituality in diabetes self-management in an urban underserved population: A qualitative exploratory study. Rhode Island Medical Journal, 97 (3), 31-35.

International Diabetes Foundation. (2015). Diabetes fact and figures. Diperoleh dari http://www. idf.org/about-diabetes/facts-figures

Johnson, K.S., Tulsky, J.A., Hays, J.C., Arnold, R.M., Olsen, M.K., Lindquist, J.H., \& Steinhauser, K.E. (2011). Which domains of spirituality are associated with anxiety and depression in patients with advanced illness? Journal of General Internal Medicine, 26 (7), 751-758. http://doi.org/10.1007/s11606-011 $-1656-2$

Kementerian Kesehatan RI. (2014). Profil kesehatan Indonesia tahun 2013. Jakarta: Kementerian Kesehatan RI. Diperoleh dari http://www.depkes.go.id/resources/downloa $\mathrm{d} /$ pusdatin/profil-kesehatan-indonesia/profilkesehatan-indonesia-2013.pdf

Koenig, H.G. (2012). Religion, spirituality, and health: The research and clinical implications. ISRN Psychiatry, 2012, Article ID 278730, 33. doi: $10.5402 / 2012 / 278730$

Lucchetti, G., Ramakrishnan, P., Karimah, A., Oliveira, G.R., Dias, A., Rane, A., ... \& Lucchetti, A.L.G. (2016). Spirituality, religiosity, and health: A comparison of physicians' attitudes in Brazil, India, and Indonesia. International Journal of Behavioral Medicine, 23(1): 63-70. DOI https://doi.org/10.1007/s12529-015-9491-1

Lloyd, C., Smith, J., \& Weinger, K. (2005). Stress and diabetes: A review of the Links. Diabetes Spectrum, 18 (2), 121-127. https://doi.org/ 10.2337/diaspect.18.2.121

Lynch, C.P., Strom, J.L., Hernandez-Tejada, M.A., \& Egede, L.E. (2012). Association between spirituality and depression in adults with type 
2 diabetes. Diabetes Educ, 38 (3), 427-435. doi: $10.1177 / 0145721712440335$

Makhija, N. (2002). Spiritual nursing. The Nursing Journal of India, 93 (6), 129-30.

Ningrum, A.W. (2014). Gambaran spiritualitas pada pasien diabetes mellitus di Puskesmas Kampung Baru Medan (Skripsi, Tidak Dipublikasi). Universitas Sumatera Utara, Medan. Diperoleh dari: http://repository.usu. ac.id/handle/123456789/45503

Rogers, M., \& Wattis, J. (2015). Spirituality in nursing practice. Nursing Standard, 29 (39), 51. http://dx.doi.org/10.7748/ns.29.39.51.e9 726

Saladin, K. (2011). Anatomy \& physiology: The Unity of Form and Function (6th Ed.). New York: The McGraw Hill Companies.

Sandra, Dewi, W.N,. \& Dewi, Y.I. (2012). Gambaran stres pada pasien gagal ginjal terminal yang menjalani terapi hemodialisa di Rumah Sakit Umum Daerah Arifin Achmad Pekanbaru. Jurnal Ners Indonesia, 2 (2), 99-108.
Sofiana, L.I., Elita, V., \&Utomo, W. (2012). Hubungan antara stress dengan konsep diri pada penderita diabetes mellitus tipe 2 . Jurnal Ners Indonesia, 2 (2), 167-176.

Wattis, J., \& Curran, S. (2006). Spirituality and mental wellbeing in old age. Geriatric Medicine, 36 (12), 13-17.

WHO. (2014). Noncommunicable diseases country profiles 2014. Geneva: WHO. Diperoleh dari http://apps.who.int/iris/bitstream/10665/128 038/1/9789241507509_eng.pdf

Wiesli, P., Schmid, C., Kerwer, O., Nigg-Koch, C., Klaghofer, R., Seifert, B., Spinas, G.A., Schwegler, K. (2005). Acute psychological stress affects glucose concentrations in patients with type 1 diabetes following food intake but not in the fasting state. Diabetes Care, 28 (8),1910-1915.

Zehtab, S., \& Adib-Hajbaghery, M. (2014). The importance of spiritual care in nursing. Nursing and Midwifery Studies, 3 (3), e22261. 